\title{
PRODUKTIVITAS PASCALARVA IKAN SEMAH Tor douronensis (Valenciennes, 1842) PADA LINGKUNGAN EX SITU DENGAN PADAT TEBAR BERBEDA
}

\author{
Jojo Subagja dan Deni Radona \\ Balai Riset Perikanan Budidaya Air Tawar dan Penyuluhan Perikanan \\ (Naskah diterima: 16 Februari 2017; Revisi final: 8 Maret 2017; Disetujui publikasi: 9 Maret 2017)
}

\begin{abstract}
ABSTRAK
Ikan semah Tor douronensis (Valenciennes, 1842) merupakan ikan asli perairan Indonesia yang memiliki potensi untuk dibudidayakan sebagai ikan konsumsi maupun ikan hias. Tujuan penelitian ini adalah mengevaluasi produktivitas (pertumbuhan, sintasan, dan biomassa) pascalarva ikan semah berdasarkan padat tebar berbeda $(10,15$, dan 20 ekor/L) sebagai kegiatan awal domestikasi. Penelitian dilakukan di Instalasi Penelitian Plasma Nutfah Perikanan Air Tawar Cijeruk, Bogor dan dilaksanakan secara eksperimental menggunakan rancangan acak lengkap dengan tiga perlakuan dan tiga kali ulangan. Pascalarva yang digunakan berukuran panjang $1,02 \pm 0,06 \mathrm{~cm}$ dan bobot 0,69 $\pm 0,08 \mathrm{mg}$; merupakan hasil pemijahan secara induksi hormon dari induk hasil tangkapan alam yang diadaptasi selama dua tahun di kolam percobaan. Pemeliharaan dilakukan dalam akuarium berukuran $40 \mathrm{~cm} \times 30 \mathrm{~cm} \times 30 \mathrm{~cm}$ dengan volume air $15 \mathrm{~L}$. Selama 40 hari pemeliharaan pascalarva diberi pakan alami berupa Artemia secara at-satiation dengan frekuensi tiga kali sehari (pagi, siang, dan sore). Hasil penelitian menunjukkan bahwa performa pertumbuhan bobot, laju pertumbuhan harian, dan sintasan tertinggi $(P<0,05)$ didapatkan pada perlakuan padat tebar 10 ekor/L dengan nilai berturut-turut 34,31 $\pm 5,29 \mathrm{mg} ; 9,80 \pm$ 0,37\% \%ari; dan 95,55 \pm 1,68\% Hasil penelitian ini merupakan informasi awal produktivitas ikan semah dalam proses domestikasi dan budidaya yang berkelanjutan.
\end{abstract}

KATA KUNCl: ikan semah; padat tebar; pertumbuhan; sintasan; pascalarva

ABSTRACT: Productivity post-larvae of mahseer Tor douronensis (Valenciennes, 1842) on ex situ environment with different densities. By: Jojo Subagja and Deni Radona

\begin{abstract}
Mahseer Tor douronensis is a native freshwater fish species of Indonesia that has the potential to be cultured for human consumption as well asfor ornamental fish. This study aimed to determine the productivity (growth, survival rate and biomass) of mahseer post-larvae based on different stocking densities (10, 15, and 20 individual/L) for domestication. This study was conducted in Germplasm Research Station, Bogor and employing completely randomized design (CRD) with threetreatments and three replications for each treatment. The post-larvae used in the experiment weresized 1.02 $\pm 0.06 \mathrm{~cm}$ in length and $0.69 \pm 0.08 \mathrm{mg}$ in weight produced from induced breeding spawning, of the broodstock natural catches was adapted for two years in pond concrete. The post-larvae were reared in aquaria (dimension $40 \mathrm{~cm}$ $\times 30 \mathrm{~cm} \times 30 \mathrm{~cm}$ ) with a volume of 15 liters water. During rearing period (40 days), post-larvae were fed with Artemia nauplii at-satiation with frequency of three times per day. The results showed significantly higher absolute weight, specific growth rate of weight, and the highest survival rate $(\mathrm{P}<0.05)$ on the treatment of stocking density 10 individual $/ \mathrm{L}$ with value of $34.31 \pm 5.29 \mathrm{mg}, 9.80 \pm 0.37 \%$ and $95.55 \pm 1.68 \%$ respectively. This result is preliminary information on productivity of mahseer for domestication, and sustainable aquaculture.
\end{abstract}

\section{KEYWORDS: mahseer; stocking densities; growth; survival rate; post-larvae}

\footnotetext{
\# Korespondensi: Balai Riset Perikanan Budidaya Air Tawar dan Penyuluhan Perikanan. Jl. Sempur No. 1, Bogor 16154, Indonesia. Tel. + (0251) 8313200

E-mail: deniradona_kkp@yahoo.com
} 


\section{PENDAHULUAN}

Ikan semah Tor douronensis (Valenciennes, 1842) atau sering disebut mahseer merupakan ikan asli perairan Indonesia yang tersebar di Sumatera, Jawa, dan Kalimantan. Ikan ini tergolong ke dalam famili Cyprinidae yang bernilai ekonomis tinggi sebagai ikan konsumsi dan komoditas hias. Untuk pasar dalam negeri, Instalasi Penelitian Plasma Nutfah Perikanan Air Tawar, Balai Penelitian dan Pengembangan Budidaya Air Tawar, Bogor menjual ikan ini dengan harga Rp500.000,00-Rp1.000.000,00/kg. Haryono et al. (2009) melaporkan bahwa harga ikan semah di Malaysia mencapai $80 \mathrm{RM} / \mathrm{kg}$, bahkan Kiat (2004) menyatakan harga ikan "kelah" nama lain dari semah di Malaysia sudah mencapai 400 RM/kg yang setara dengan Rp1.200.000,00/kg. Lebih lanjut Yohanes \& Dede (2016) melaporkan harga ikan semah untuk ukuran 2-3 kg sebesar Rp2.500.000,00.

Dalam manajemen kegiatan budidaya dan keberhasilan proses domestikasi, salah satu kegiatannya adalah pendederan. Pendederan dilakukan pada lingkungan di luar habitatnya (ex situ). Pendederan merupakan kegiatan lanjutan setelah pemijahan dan larva ikan akan dipisahkan dengan induknya. Menurut Pawartining et al. (2003), pendederan perlu dilakukan untuk mendapatkan benih yang berkualitas sebelum ditebar di kolam pembesaran. Pada tahap pendederan diperlukan penentuan padat tebar agar sintasan dan pertumbuhan ikan tetap optimal. Peningkatan padat tebar sampai batas tertentu dapat mengganggu proses fisiologis, menurunkan pertumbuhan, dan sintasan (Wedemeyer, 2001). Pengaturan padat tebar dapat meningkatkan nilai produksi berbagai komoditas. Penelitian padat tebar pada ikan-ikan air tawar potensial dan lokal prospektif yang sudah dilakukan antara lain, ikan lalawak Barbonymus balleroides (Kusmini et al., 2017), ikan uceng Nemacheilus fasciatus (Prakoso et al., 2016), ikan tambakan Helostoma temminckii (Joko et al., 2013), ikan mas rajadanu Cyprinus carpio (Radona et al., 2012), ikan nila BEST Oreochromis niloticus, dan nilem Osteochilus vittatus (Radona et al., 2011), ikan lele Clarias gariepinus (Hermawan et al., 2012), dan jenis krustasea seperti lobster Cherax quadricarinatus (Budiardi et al., 2008).

Sejauh ini penelitian terkait pendederan ikan genus Tor sudah dilakukan pada larva ikan Tor soro. Asih et al. (2011) melaporkan pendederan dilakukan pada akuarium ukuran $100 \mathrm{~cm} \times 60 \mathrm{~cm} \times 40 \mathrm{~cm}$ dengan kepadatan 1.000 ekor. Pada ikan semah diperlukan pengaturan padat tebar karena data dan informasi tentang padat penebarannya masih belum ada dan akan menjadi penting dalam menunjang keberhasilan domestikasi dan upaya peningkatan produksi.
Penelitian ini bertujuan untuk mengevaluasi produktivitas (pertumbuhan, sintasan, dan biomassa) pascalarva ikan semah yang dipelihara pada akuarium dengan padat tebar yang berbeda.

\section{BAHAN DAN METODE}

Penelitian dilakukan di Instalasi Penelitian Plasma Nutfah Perikanan Air Tawar Cijeruk, Bogor. Penelitian dilakukan secara eksperimental menggunakan rancangan acak lengkap dengan tiga perlakuan padat tebar ikan per liter air, yaitu: (A) 10 ekor/L (150 ekor per akuarium), (B) 15 ekor/L (225 ekor per akuarium), dan (C) 20 ekor/L (300 ekor per akuarium), masingmasing dengan tiga ulangan.

Ikan semah yang digunakan berumur empat hari atau pascalarva (kandungan kuning telur habis) yang berukuran panjang $1,02 \pm 0,06 \mathrm{~cm}$ dan bobot 0,69 \pm $0,08 \mathrm{mg}$; merupakan hasil pemijahan secara induksi hormon (Asih et al., 2004) dari induk hasil tangkapan alam yang diadaptasi selama dua tahun di kolam percobaan. Pemeliharaan pascalarva dilakukan pada sembilan akuarium berukuran $40 \mathrm{~cm} \times 30 \mathrm{~cm} \times 30 \mathrm{~cm}$ dengan volume air sebanyak $15 \mathrm{~L}$. Setiap akuarium diberi sistem aerasi dengan intensitas yang sama. Selama 40 hari pemeliharaan pascalarva diberi pakan alami berupa nauplii Artemia secara at-satiation dengan frekuensi tiga kali sehari (pagi, siang, dan sore). Kondisi kualitas air dalam akuarium dijaga dengan penyifonan dan penggantian air sebanyak $30 \% 50 \%$ setiap tiga hari.

Pertumbuhan panjang, bobot, laju pertumbuhan harian, dan sintasan diamati setiap 10 hari. Sampling pertumbuhan dilakukan dengan mengukur panjang dan bobot individu sebanyak 15\%dari total populasi per akuarium. Pengamatan biomassa dilakukan pada akhir penelitian. Paramater yang diamati dihitung berdasarkan rumus menurut Effendie (2002).

Pertumbuhan panjang mutlak

$$
\mathrm{P}=\mathrm{Pt}-\mathrm{Po}
$$

di mana:

$\mathrm{P}=$ pertumbuhan panjang $(\mathrm{cm})$
$\mathrm{Pt}=$ panjang akhir ikan hari ke-t $(\mathrm{cm})$
$\mathrm{Po}=$ panjang awal ikan $(\mathrm{cm})$

Pertumbuhan bobot mutlak

$$
\mathrm{W}=\mathrm{Wt}-\mathrm{W}_{0}
$$

di mana:

$\mathrm{W}=$ pertumbuhan bobot $(\mathrm{mg})$

$\mathrm{Wt}=$ bobot akhir ikan hari ke-t $(\mathrm{mg})$

Wo = bobot awal ikan (mg) 
Laju pertumbuhan harian

$$
\mathrm{LPH}=\frac{\mathrm{LnW}_{\mathrm{t}}-\mathrm{LnW}_{0}}{\mathrm{t}} \times 100
$$

di mana:

$\mathrm{LPH}=$ laju pertumbuhan harian (\%hari)

$\mathrm{W}_{\mathrm{t}}=$ bobot rata-rata ikan pada saat akhir $(\mathrm{g})$

$\mathrm{W}_{0}=$ bobot rata-rata ikan pada saat awal (g)

$\mathrm{t}=$ lama pemeliharaan (hari)

Sintasan

$$
\mathrm{SR}=\frac{\mathrm{N}_{\mathrm{t}}}{\mathrm{N}_{0}} \times 100
$$

di mana:

$\mathrm{SR}=\operatorname{sintasan}(\%$

$\mathrm{Nt}=$ jumlah benih awal pemeliharaan (ekor)

$\mathrm{N}_{0}=$ jumlah benih akhir pemeli haraan (ekor)

Biomassa

$$
B M=\frac{B M t-B M d}{B M 0}
$$

di mana:

$\mathrm{BM}=$ biomassa $(\mathrm{g})$

$\mathrm{BMt}=$ biomassa ikan pada akhir penelitian $(\mathrm{g})$

$\mathrm{BM} d=$ biomassa ikan mati selama penelitian $(\mathrm{g})$

$\mathrm{Bmo}=$ biomassa ikan pada awal penelitian $(\mathrm{g})$

Sebagai data pendukung dilakukan pengamatan kondisi air di akuarium pada hari kedua pemeliharaan (sehari sebelum penyifonan) dengan selang tiga jam selama 24 jam. Parameter suhu $\left({ }^{\circ} \mathrm{C}\right), \mathrm{pH}$, dan oksigen terlarut (mg/L) diukur langsung saat pengamatan menggunakan Multi Parameter Water Quality Meter EC 900. Alkalinitas $(\mathrm{mg} / \mathrm{L})$, nitrat $(\mathrm{mg} / \mathrm{L})$, nitrit $(\mathrm{mg} / \mathrm{L})$, kesadahan ( $\mathrm{mg} / \mathrm{L} \mathrm{CaCO}_{3}$ ), dan TOM (Total organic matter) (mg/L) diamati di laboratorium Uji Balai Penelitian dan Pengembangan Budidaya Air Tawar, Bogor yang sudah terakreditasi ISO 17025:2008 (LP711 IDN).

Data yang diperoleh kemudian ditabulasi dan produktivitas (pertumbuhan, sintasan, dan biomassa) pada akhir penelitian dianalisa dengan analisis varian (ANOVA) pada selang kepercayaan 95\% Perbedaan antar perlakuan dianalisis lanjut dengan uji lanjut Duncan menggunakan bantuan program SPSS versi 18. Untuk data parameter air dianalisis secara kuantitatif.

\section{HASIL DAN BAHASAN}

\section{Performa Pertumbuhan}

Hasil penelitian selama 40 hari menunjukkan bahwa ikan semah pascalarva dengan kepadatan 10 ekor/L memiliki performa pertumbuhan bobot lebih baik $(P<0,05)$ dibandingkan dengan kepadatan 15 dan 20 ekor/L (Tabel 1). Nilai pertumbuhan panjang, bobot, dan laju pertumbuhan harian ikan semah pascalarva selama penelitian disajikan pada Tabel 1 dan pertumbuhan panjang dan bobot setiap 10 hari pemeliharaan ditampilkan pada Gambar 1 dan 2.

Perlakuan padat tebar memiliki pengaruh yang kuat pada pertumbuhan ikan, karena ruang dan makanan menjadi salah satu faktor yang memengaruhi pertumbuhan. Dari nilai pertumbuhan ikan yang diperoleh pada perlakuan padat tebar 10 ekor/L memiliki bobot badan lebih besar $19,43 \%$ daripada perlakuan padat tebar 15 ekor/L dan 11,97\%daripada perlakuan padat tebar 20 ekor/L. Berdasarkan pengamatan selama penelitian, optimalnya pertumbuhan bobot pascalarva ikan semah pada padat tebar 10 ekor/L diduga karena mampu memanfaatkan ruang dan makanan dengan lebih baik sehingga berdampak positif pada pertumbuhan ikan, sedangkan rendahnya nilai pertumbuhan bobot yang diperoleh pada padat tebar 15 dan 20 ekor/L diduga karena ruang menjadi sempit sehingga menghambat ikan untuk tumbuh optimal. Penelitian ini serupa dengan penelitian yang dilakukan pada ikan uceng (Prakoso et al., 2016), African catfish (Coulibaly et al., 2007), dan silver perch (Rowland et al., 2006).

Nilai laju pertumbuhan bo bot harian yang diperoleh berbanding lurus dengan nilai pertumbuhan bobot yang didapatkan, semakin tinggi nilai pertumbuhan maka semakin besar nilai laju pertumbuhan harian yang dihasilkan. Pada penelitian ini diperoleh nilai laju pertumbuhan bobot terbaik pada perlakuan padat tebar 10 ekor/L sebesar 9,80 $\pm 0,37 \%$ Secara statistik nilai ini berbeda nyata $(P<0,05)$ dengan perlakuan padat tebar 15 ekor/L. Padat tebar merupakan faktor penting yang harus dipertimbangkan dalam budidaya ikan. Beberapa studi telah mengevaluasi pengaruh padat tebar terhadap pertumbuhan dan metabolisme pada spesies ikan budidaya, terutama ikan-ikan lokal (Kusmini et al., 2017; Rahman et al., 2016; Prakoso et al., 2016; Joko et al., 2013; Li et al., 2012; dan Herrera et al., 2009). Kegiatan budidaya membutuhkan optimalisasi padat tebar sepanjang siklus hidup dari spesies yang dipelihara untuk menghindari aktivasi sistem stres dan konsekuensi kerugian ekonomi (Jia et al., 2016; Barton, 2002).

\section{Sintasan}

Sintasan ikan semah yang dipelihara dengan perlakuan padat tebar berbeda disajikan pada Gambar 3. Nilai sintasan setiap perlakuan relatif tinggi $(>90 \%$. Hasil penelitian menunjukkan pada perlakuan padat tebar 10 ekor/L memiliki sintasan tertinggi dengan nilai $95,55 \pm 1,68 \%(P<0,05)$.

Nilai sintasan tertinggi pada perlakuan padat tebar 10 ekor/L $(95,55 \%)$ ini sama halnya dengan nilai 
Tabel 1. Pertumbuhan panjang, bobot, dan laju pertumbuhan harian ikan semah pascalarva selama 40 hari pemeliharaan

Table 1. Growth of length, weight and specific growth rate of mahseer post-larvae for 40 days of rearing

\begin{tabular}{|c|c|c|c|}
\hline \multirow{2}{*}{$\begin{array}{l}\text { Parameter pertumbuhan } \\
\text { Growth parameters }\end{array}$} & \multicolumn{3}{|c|}{ Padat tebar (Stocking densities) } \\
\hline & $\begin{array}{c}10 \mathrm{ekor} / \mathrm{L} \\
10 \text { individual } / \mathrm{L}\end{array}$ & $\begin{array}{c}15 \mathrm{ekor} / \mathrm{L} \\
15 \text { individual/L }\end{array}$ & $\begin{array}{l}20 \text { ekor } / L \\
20 \text { individual/L }\end{array}$ \\
\hline $\begin{array}{l}\text { Panjang awal } \\
\text { Initial length }(\mathrm{cm})\end{array}$ & $1.02 \pm 0.06$ & $1.02 \pm 0.06$ & $1.02 \pm 0.06$ \\
\hline $\begin{array}{l}\text { Bobot awal } \\
\text { Initial body weight }(\mathrm{mg})\end{array}$ & $0.69 \pm 0.08$ & $0.69 \pm 0.08$ & $0.69 \pm 0.08$ \\
\hline $\begin{array}{l}\text { Panjang akhir } \\
\text { Final length }(\mathrm{cm})\end{array}$ & $1.17 \pm 0.04$ & $1.14 \pm 0.02$ & $1.12 \pm 0.02$ \\
\hline $\begin{array}{l}\text { Bobot akhir } \\
\text { Final body weight (mg) }\end{array}$ & $35.00 \pm 5.29$ & $28.33 \pm 1.15$ & $31.33 \pm 0.58$ \\
\hline $\begin{array}{l}\text { Panjang mutlak } \\
\text { Absolute length }(\mathrm{cm})\end{array}$ & $0.15 \pm 0.04^{\mathrm{a}}$ & $0.12 \pm 0.02^{\mathrm{a}}$ & $0.10 \pm 0.02^{a}$ \\
\hline $\begin{array}{l}\text { Bobot mutlak } \\
\text { Absolute weight (mg) }\end{array}$ & $34.31 \pm 5.29^{\mathrm{a}}$ & $27.64 \pm 1.16^{b}$ & $30.64 \pm 0.58^{\mathrm{ab}}$ \\
\hline $\begin{array}{l}\text { LPH panjang (\%hari) } \\
\text { Specific growth rate of length (\%day) }\end{array}$ & $0.33 \pm 0.09^{\mathrm{a}}$ & $0.27 \pm 0.05^{\mathrm{a}}$ & $0.23 \pm 0.04^{a}$ \\
\hline $\begin{array}{l}\text { LPH bobot (\%/hari) } \\
\text { Specific growth rate of weight (\%day) }\end{array}$ & $9.80 \pm 0.37^{a}$ & $9.29 \pm 0.10^{b}$ & $9.54 \pm 0.05^{\mathrm{ab}}$ \\
\hline
\end{tabular}

Keterangan (Remarks): $\quad$ Angka yang diikuti huruf superskrip yang sama pada baris yang sama menunjukkan tidak adanya perbedaan nyata menurut $\mathrm{Uji}$ Duncan $(P>0,05)$ (Numbers followed by the same superscript letter in the same line indicates no significantly difference $(P>0.05)$ )

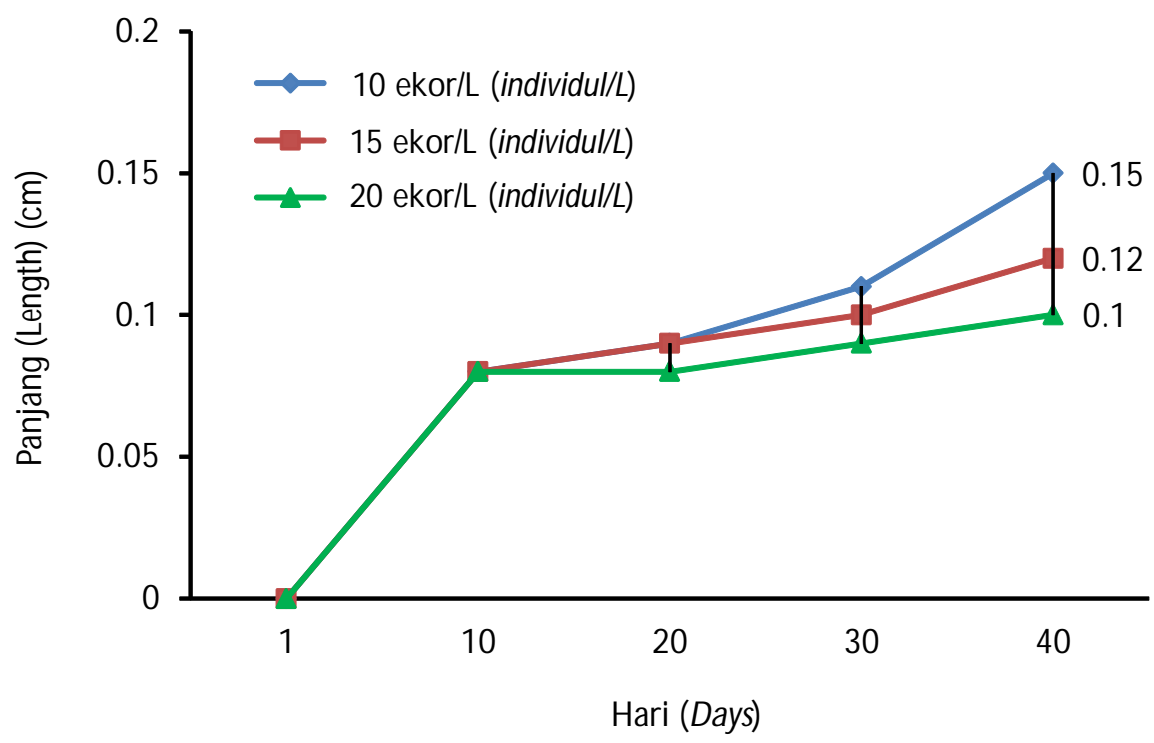

Gambar 1. Pertumbuhan panjang ikan semah pascalarva dipelihara dengan padat tebar berbeda

Figure 1. Growth of length of mahseer post-larvae reared with different densities 


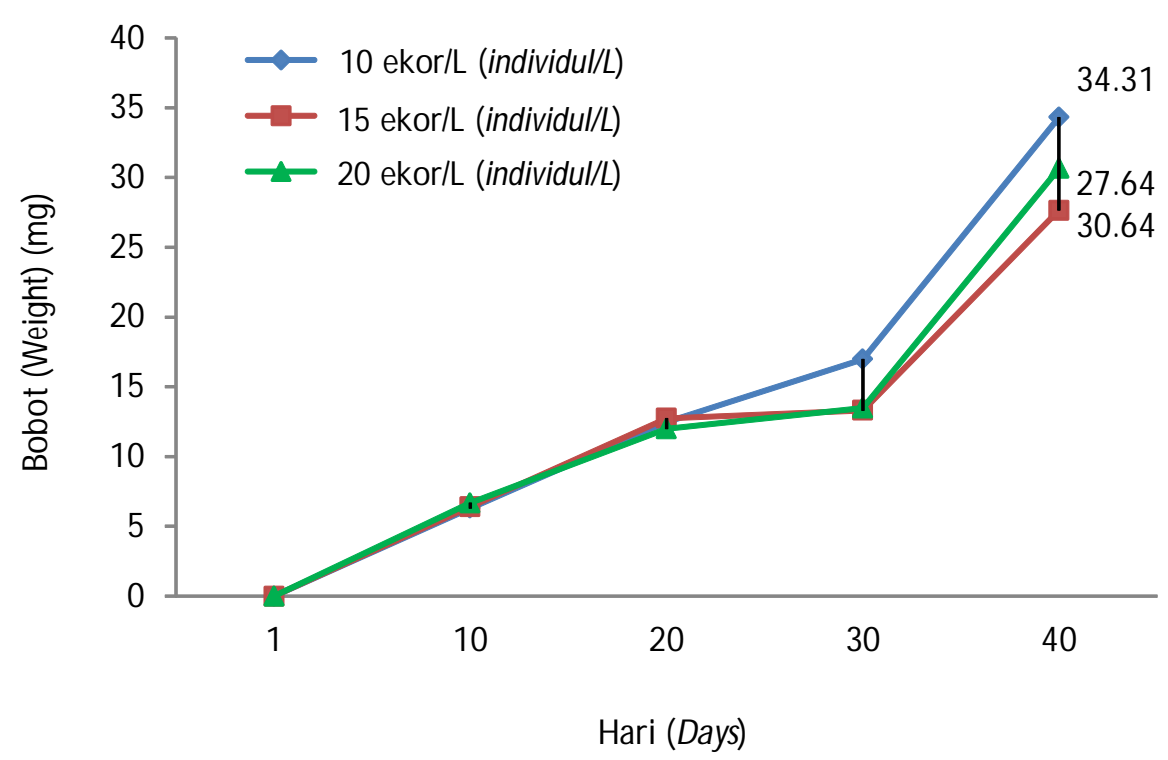

Gambar 2. Pertumbuhan bobot ikan semah pascalarva dipelihara dengan padat tebar berbeda

Figure 2. Growth of weigth of mahseer post-larvae reared with different densities

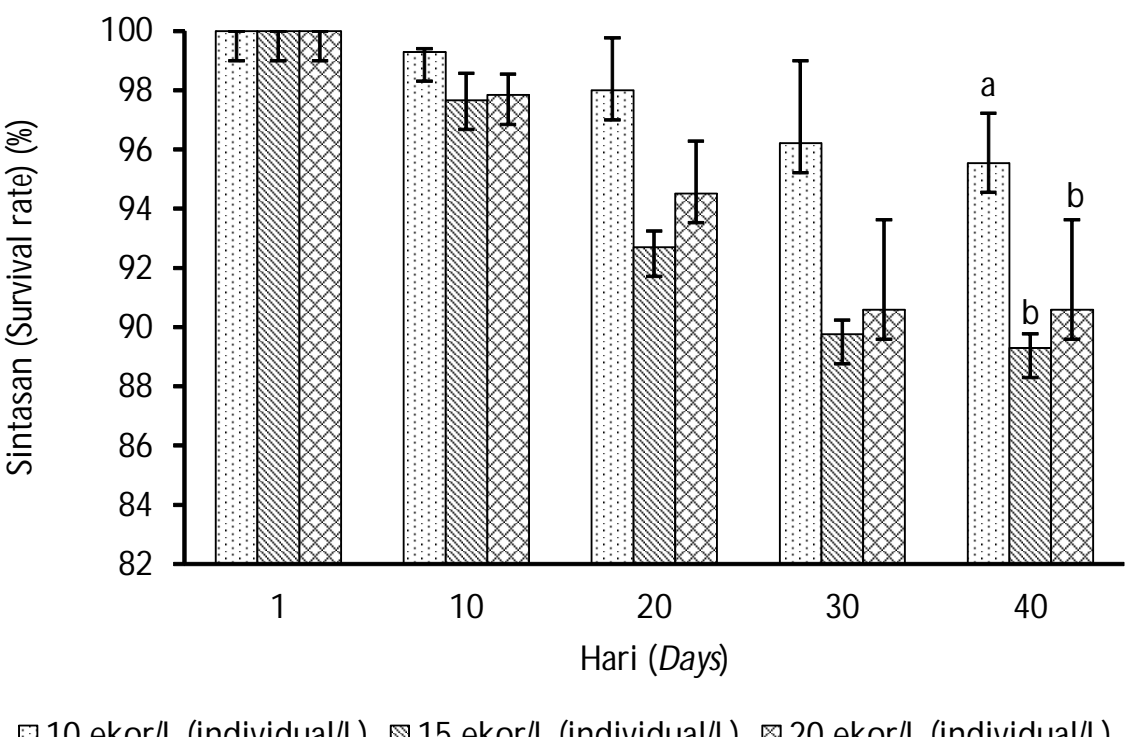

Gambar 3. Sintasan ikan semah pascalarva dipelihara dengan padat tebar berbeda

Figure 3. Survival rate of mahseer post-larvae reared with different densities

sintasan yang diperoleh pada penelitian sebelumnya. Radona et al. (2015) melaporkan nilai sintasan pada pendederan ikan semah di akuarium ukuran $40 \mathrm{~cm} x$ $30 \mathrm{~cm} \times 30 \mathrm{~cm}$ dengan kepadatan 80 ekor mencapai $96 \%$ Rendahnya sintasan pada perlakuan padat tebar 15 dan 20 ekor/L diduga jumlah kepadatan di atas batas toleransi. Kepadatan yang tinggi cenderung akan membuat ikan mudah menjadi stres (Jia et al., 2016; Rezeki et al., 2013). Padat tebar yang lebih banyak dapat mengakibatkan terjadinya kompetisi baik dalam hal pakan dan pemanfaatan oksigen terlarut. Selain itu, menurut Kholifah et al. (2008), padat tebar yang tinggi akan menyebabkan tingkat persaingan ruang gerak yang dapat menurunkan sintasan suatu organisme. Ikan-ikan yang memiliki fisik yang lebih kuat akan dominan dalam bersaing sehingga memiliki peluang yang lebih besar dalam memperoleh pakan yang diberikan. Nilai sintasan yang diperoleh pada 
perlakuan padat tebar tinggi (20 ekor/L) menunjukkan jarak kisaran yang lebih tinggi dibandingkan dengan perlakuan padat tebar 10 dan 15 ekor/L.

\section{Biomassa}

Biomassa ikan semah pascalarva yang diperoleh selama 40 hari penelitian disajikan pada Tabel 2. Nilai biomassa yang diperoleh pada perlakuan padat tebar 10 dan 15 ekor/L, secara statistik menunjukkan nilai yang tidak berbeda nyata $(P>0,05)$ dan berbeda dengan perlakuan padat tebar 20 ekor $/ L(P<0,05)$.

Biomassa merupakan bobot semua ikan yang masih hidup selama akhir pemeliharaan. Parameter biomassa yang diperoleh pada perlakuan padat tebar 10 ekor/L $(4.419,12 \pm 845,02 \mathrm{mg})$ dan padat tebar 15 ekor/L $(4.611,67 \pm 486,47 \mathrm{mg})$ menunjukkan hasil yang sama $(P>0,05)$ dan berbeda dengan perlakuan padat tebar 20 ekor/L $(6.995,78 \pm 186,74 \mathrm{mg})$. Tingginya nilai biomassa yang diperoleh pada perlakuan padat tebar 20 ekor/L dikarenakan jumlah individu pada saat awal pemeliharaan dalam satu populasi memang sudah lebih banyak dibandingkan dengan perlakuan lain. Nilai biomassa sangat dipengaruhi oleh sintasan dan efisiensi dalam memanfaatkan pakan (Mulyadi et al., 2010). Berdasarkan pengamatan yang dilakukan bahwa pemanfaatan energi pakan pada ikan semah pascalarva dengan kepadatan 10 ekor/Llebih efektif dengan nilai pertumbuhan yang tertinggi. Biomassa pada umumnya berbanding lurus dengan sintasan benih ikan uji.

\section{Kualitas Air}

Hasil pengukuran kualitas air selama penelitian disajikan pada Tabel 3. Pengukuran kondisi air pada akuarium dilakukan untuk menunjang kegiatan pemeliharaan karena lingkungan memengaruhi keberhasilan dalam proses budi daya terutama pertumbuhan. Pertumbuhan sangat dipengaruhi oleh suhu, pH, oksigen terlarut, dan alkalinitas (Oliveira et al., 2012; Mallya, 2007). Suhu air yang optimal akan meningkatkan aktivitas makan ikan sehingga

Tabel 2. Biomassa pascalarva ikan semah setiap perlakuan selama 40 hari pemeliharaan

Table 2. Postlarvae biomass of mahseer for 40 days of rearing

\begin{tabular}{cc}
\hline $\begin{array}{c}\text { Padat tebar } \\
\text { Stocking densities }\end{array}$ & \multicolumn{1}{c}{$\begin{array}{c}\text { Biomassa } \\
\text { Biomass }(\mathbf{m g})\end{array}$} \\
\hline 10 ekor/L (10 individual/L) & $4,419.12 \pm 845.02^{\mathrm{a}}$ \\
15 ekor/L (15 individual/L) & $4,611.67 \pm 486.47^{\mathrm{a}}$ \\
20 ekor/L (20 individual/L) & $6,995.78 \pm 186.74^{\mathrm{b}}$ \\
\hline Keterangan (Remarks): & Angka yang diikuti huruf superskrip \\
& yang sama pada lajur yang sama \\
& menunjukkan tidak adanya \\
& perbedaan nyata menurut Uji \\
& Duncan (P>0,05) (Numbers followed \\
& by the same superscript letter in \\
& the same line indicates no signifi \\
& cantly difference (P>0.05))
\end{tabular}

Tabel 3. Nilai kualitas air selama penelitian

Table 3. The value of water quality during the experiment

\begin{tabular}{lc}
\hline \multicolumn{1}{c}{$\begin{array}{c}\text { Variabel (kualitas air) } \\
\text { Variable (water quality) }\end{array}$} & $\begin{array}{c}\text { Kisaran } \\
\text { Range }\end{array}$ \\
\hline Suhu (Temperature) $\left({ }^{\circ} \mathrm{C}\right)$ & $22-26$ \\
$\mathrm{pH}$ & $6-7$ \\
Oksigen terlarut (Dissolved oxygen) $(\mathrm{mg} / \mathrm{L})$ & $5.31-6.8$ \\
Alkalinitas (Alkalinity) $(\mathrm{mg} / \mathrm{L})$ & $88.4-91.1$ \\
Nitrit (Nitrite) $(\mathrm{mg} / \mathrm{L})$ & $0.014-0.018$ \\
Nitrat (Nitrate) $(\mathrm{mg} / \mathrm{L})$ & $0.76-1.47$ \\
Kesadahan (Hardness) $\left(\mathrm{mg} / \mathrm{L} \mathrm{CaCO}_{3}\right)$ & $93.0-93.5$ \\
TOM (Total organic matter) $\left(\mathrm{mg}^{\prime} / \mathrm{L}\right)$ & $5.10-9.20$ \\
\hline
\end{tabular}


mempercepat pertumbuhan. Secara umum nilai parameter kualitas air yang terukur (Tabel 3) dapat mendukung sintasan dan proses pertumbuhan ikan semah pascalarva yang dipelihara (Radona et al., 2015; Subagja et al., 2013). Tidak ada perbedaan yang signifikan antara nilai kualitas air pada setiap perlakuan padat tebar, hal ini dikarenakan penelitian dilakukan secara terkontrol di hatcheri.

\section{KESIMPULAN}

Ikan semah stadia pascalarva dengan padat tebar 10 ekor/L dapat memberikan pertumbuhan dan sintasan yang optimal pada pemeliharaan selama 40 hari di akuarium.

\section{UCAPAN TERIMA KASIH}

Ucapan terima kasih diberikan kepada Bapak Sudarmaji, Heppy Aprilistanto, dan mahasiswa praktek kerja lapangan (PKL) Fakultas Perikanan dan IImu Kelautan Universitas Riau (Rozi Ramadhani Putra dan Mei Dinar Haloho) atas bantuan teknis yang diberikan.

\section{DAFTAR ACUAN}

Asih, S., Subagja, J., Kristanto, A.H., Nugroho, E., \& Gustiano, R. (2011). Permohonan pelepasan ikan Tor soro hasil domestikasi. Naskah Akademik, Balai Penelitian dan Pengembangan Budidaya Air Tawar. Bogor, $26 \mathrm{hlm}$.

Asih, S., Subagja, J., Winarlin, \& Widiyati, A. (2004). Penguasaan teknik pembenihan dan pembesaran ikan batak: peningkatan kualitas telur melalui perlakuan hormonal pada penyuntikan awal dalam berbagai dosis dan selang waktu berbeda. Laporan Hasil Penelitian Balai Riset Perikanan Budidaya Air Tawar. Bogor, hlm. 314-323.

Barton, B.A. (2002). Stress in fishes: a diversity of responses with particular reference to changes in circulating corticosteroids. Integrated Comparative Biology, 42, 517-525.

Budiardi, T., Irawan, D., \& Wahjuningrum, D. (2008). Pertumbuhan dan kelangsungan hidup lobster capit merah Cherax quadricarinatus dipelihara pada sistem resirkulasi dengan kepadatan berbeda. Jurnal Akuakultur Indonesia, 7(2), 109-114.

Coulibaly, A., Ouattara, I.N., Kone, T., N'Douba, V., Snoeks, J., Bi, G.G., \& Kouamelan, E.P. (2007). First results of floating cage culture of the African catfish Heterobranchus longifilis Valenciennes, 1840: Effect of stocking density on survival and growth rates. Aquaculture, 263, 61-67.

Effendie, M.I. (2002). Biologi perikanan. Yayasan Pustaka Nusatama. Yogyakarta, $163 \mathrm{hlm}$.
Haryono, A., Tjakrawaidjaja, \& Wahyudewantoro, G. (2009). Proses domestikasi dan reproduksi ikan tambra yang telah langka menuju budidayanya. Pusat Penelitian Biologi, LIPI Press. Jakarta, hlm. 2-15.

Hermawan, A.T., Iskandar, \& Subhan, U. (2012). Pengaruh padat tebar terhadap kelangsungan hidup pertumbuhan lele dumbo Clarias gariepinus Burch di kolam Kali Menir Indramayu. Jurnal Perikanan Kelautan, 3(3), 85-93.

Herrera, M., Vargas-Chacoff, L., Hachero, I., RuizJarabo, I., Rodiles, A., Navas, J.I., \& Mancera, J.M. (2009). Physiologycal responses of juvenile wedge sole Dicologoglossa cuneata Moreau to high stocking density. Aquaculture Research, 40, 790-797.

Jia, R., Liu, B.L., Feng, W.R., Han, C., Huang, B., \& Lei, J.L. (2016). Stress and immune responses in skin of turbot Scophthalmus maximus under different stocking densities. Fish and Shellfish Immunology, 55, 131-139.

Joko, Muslim, \& Taqwa, F. (2013). Pendederan larva ikan tambakan Helostoma temmincki dengan padat tebar berbeda. Jurnal Perikanan dan Kelautan, 18(2), 59-67.

Kholifah, U., Trisyani, N., \& Yuniar, I. (2008). Pengaruh padat tebar yang berbeda terhadap kelangsungan hidup dan pertumbuhan pada polikultur udang windu Penaeus monodon dan ikan bandeng Chanos chanos pada hapa di tambak Brebes-Jawa Tengah. Neptunus, 14(2), 152-158.

Kiat, Ng Chi. (2004). The kings of the rivers Mahseer in Malayan and the region. Inter sea Fishery, Selangor, Malaysia, $170 \mathrm{pp}$.

Kusmini, I.I., Putri, F.P., \& Radona, D. (2017). Pertumbuhan dan sintasan pascalarva ikan lalawak Barbonymus balleroides Valenciennes, 1842 di akuarium dengan kepadatan berbeda. Jurnal Iktiologi Indonesia, 17(1), Februari 2017. Siap terbit.

Li, D., Liu, Z., \& Xie, C. (2012). Effect of stocking density on growth and serumconcentrationes of thyroid hormones and cortisol in Amur sturgeon, Acipenser schrenckii. Fish Physiology Biochemistry, 38, 511-520.

Mallya, Y.J. (2007). The effects of dissolved oxygen on fish growth in aquaculture. UNU-Fisheries Training Programme, $30 \mathrm{pp}$.

Mulyadi, Usman, M.T., \& Suryani. (2010). Pengaruh frekuensi pemberian pakan yang berbeda terhadap pertumbuhan dan kelulushidupan benih silais Ompok hypophthalmus. Terubuk, 38(2), 21-40.

Oliveira, E.G., Pinheiro, A.B., Oliveira, V.Q., Junior, A.R., Moraes, M.G., Rocha, I.R., Sousa, R.R., \& 
Costa, F.H. (2012). Effect of stocking density on the performance of juvenile pirarucu Arapaima gigas in cages. Aquaculture, 370, 96-101.

Pawartining, Y., Kadarini, T., Rusmaedi, \& Subandiyah, S. (2003). Pengaruh padat penebaran terhadap pertumbuhan dan sintasan dederan ikan nila Gift Oreochromis niloticus di kolam. Jurnal Iktiologi Indonesia, 3(2), 63-66.

Prakoso, V.A., Ath-thar, M.H.F., Subagja, J., \& Kristanto, A.H. (2016). Pertumbuhan ikan uceng Nemacheilus fasciatus dengan padat tebar berbeda dalam lingkungan ex situ. J. Ris. Akuakultur, 11(4), 355-362.

Radona, D., Subagja, J., \& Arifin, O.Z. (2015). Performa reproduksi induk dan pertumbuhan benih ikan Tor hasil persilangan Tor soro dan Tor douronensis secara resiprokal. J. Ris. Akuakultur, 10(3), 335-343.

Radona, D., Asih, S., \& Huwoyon, G.H. (2012). Optimalisasi kepadatan benih ikan mas Cyprinus carpio strain rajadanu pada pendederan di kolam air tenang. Berita Biologi, 11(2), 161-166.

Radona, D., Prakoso, V.A., \& Ath-thar, M.F.H. (2011). Padat tebar ikan nila Oreochromis niloticus yang dipelihara secara polikultur dengan ikan nilem Osteochilus vittatus di kolam air tenang. Prosiding Seminar Nasional Hasil Penelitian Perikanan dan Kelautan. Sekolah Tinggi Perikanan, Jakarta, Indonesia, hlm. 107-113.
Rahman, M.M., Chowdhury, P., \& Islam, M.S. (2016). Effects of stocking density on growth and production performance of monosex male tilapia Oreochromis niloticus in earthen ponds. International Journal of Fisheries and Aquatic Studies, 4(3), 267271.

Rezeki, S., Hastuti, S., \& Elfitasari, T. (2013). Uji coba budidaya nila Larasati di keramba jaring apung dengan padat tebar berbeda. Jurnal Saintek Perikanan, 9(1), 29-39.

Rowland, S.J., Mifsud, C., Nixon, M., \& Boyd, P. (2006). Effect of stocking density on the performance of the Australian freshwater silver perch Bidyanus bidyanus. Aquaculture, 253, 301-308.

Subagja, J., Radona, D., Cahyanti, W., \& Asih, S. (2013). Pembenihan Ikan semah Tor douronensis. Val. 1842. Laporan teknis penelitian APBN BPPBAT Bogor. Unpublished.

Wedemeyer, G. (2001). Fish hatchery management. Second edition. American Fisheries Society. New York, $751 \mathrm{pp}$.

Yohanes, \& Dede. (2016). Ikan ringau dan semah memiliki potensi ekspor. www.thetanjungpuratimes.com. Diakses pada tanggal 21 Februari 2017 pukul. 08.13 WIB. 